OPEN ACCESS

Edited by:

Hideyuki Inui,

Kobe University, Japan

Reviewed by:

Kate Warpeha,

University of Illinois at Chicago, USA

Yi Ma,

University of Connecticut, USA

*Correspondence:

Ahmad H. Kabir

ahmad.kabir@ru.ac.bd

Specialty section:

This article was submitted to Plant Traffic and Transport,

a section of the journal

Frontiers in Plant Science

Received: 15 February 2016

Accepted: 13 July 2016

Published: 27 July 2016

Citation:

Kabir AH, Hossain MM, Khatun MA Mandal A and Haider SA (2016) Role of Silicon Counteracting Cadmium Toxicity in Alfalfa (Medicago sativa L.). Front. Plant Sci. 7:1117. doi: 10.3389/fpls.2016.01117

\section{Role of Silicon Counteracting Cadmium Toxicity in Alfalfa (Medicago sativa L.)}

\author{
Ahmad H. Kabir ${ }^{*}$, Mohammad M. Hossain ${ }^{1}$, Most A. Khatun ${ }^{1}$, Abul Mandal' ${ }^{2}$ and \\ Syed A. Haider ${ }^{1}$
}

${ }^{1}$ Plant and Crop Physiology Laboratory, Department of Botany, University of Rajshahi, Rajshahi, Bangladesh, ${ }^{2}$ System Biology Research Center, School of Bioscience, University of Skövde, Skövde, Sweden

Cadmium (Cd) is one of the most phytotoxic elements causing an agricultural problem and human health hazards. This work investigates whether and how silicon (Si) ameliorates $\mathrm{Cd}$ toxicity in Alfalfa. The addition of $\mathrm{Si}$ in $\mathrm{Cd}$-stressed plants caused significant improvement in morpho-physiological features as well as total protein and membrane stability, indicating that Si does have critical roles in Cd detoxification in Alfalfa. Furthermore, Si supplementation in Cd-stressed plants showed a significant decrease in $\mathrm{Cd}$ and $\mathrm{Fe}$ concentrations in both roots and shoots compared with $\mathrm{Cd}$ stressed plants, revealing that Si-mediated tolerance to $\mathrm{Cd}$ stress is associated with $\mathrm{Cd}$ inhibition in Alfalfa. Results also showed no significant changes in the expression of two metal chelators [MSPCS1 (phytochelatin synthase) and MSMT2 (metallothionein)] and $\mathrm{PC}$ (phytochelatin) accumulation, indicating that there may be no metal sequestration or change in metal sequestration following Si application under Cd stress in Alfalfa. We further performed a targeted study on the effect of Si on Fe uptake mechanisms. We observed the consistent reduction in Fe reductase activity, expression of Fe-related genes [MsIRT1 (Fe transporter), MsNramp1 (metal transporter) and OsFRO1 (ferric chelate reductase] and Fe chelators (citrate and malate) by Si application to Cd stress in roots of Alfalfa. These results support that limiting Fe uptake through the downregulation of $\mathrm{Fe}$ acquisition mechanisms confers Si-mediated alleviation of $\mathrm{Cd}$ toxicity in Alfalfa. Finally, an increase of catalase, ascorbate peroxidase, and superoxide dismutase activities along with elevated methionine and proline subjected to Si application might play roles, at least in part, to reduce $\mathrm{H}_{2} \mathrm{O}_{2}$ and to provide antioxidant defense against $\mathrm{Cd}$ stress in Alfalfa. The study shows evidence of the effect of Si on alleviating Cd toxicity in Alfalfa and can be further extended for phytoremediation of $\mathrm{Cd}$ toxicity in plants.

Keywords: Alfalfa, silicon, Fe regulation, antioxidant activities, Cd stress

\section{INTRODUCTION}

Cadmium (Cd) is a toxic heavy metal affecting plant yield and environment (Järup and Åkesson, 2009; Naeem et al., 2015). It exhibits varied degrees of phytotoxicity and may replace essential metals or cofactors at enzyme active site causing an imbalance in cellular redox status (Hattab et al., 2014). Furthermore, $\mathrm{Cd}$ at toxic level displaces protein structure and disrupts membrane integrity (Rascio and Navarri-Izzo, 2011). Cd is naturally high in agricultural soils due to anthropogenic 
release and is frequently accumulated in plants. Alfalfa (Medicago sativa L.) is an important forage crop and can accumulate heavy metals, such as Cd, Ni, Cu, Zn, Vn (Peralta-Videa et al., 2002; Yang et al., 2011; Carrasco-Gil et al., 2012). Alfalfa is a source of biological nitrogen fixation, bio-fuel and animal feed. Therefore, reducing Cd bioaccumulation in Alfalfa deserves attention.

Silicon ( $\mathrm{Si}$ ) is an abundant element in the Earth's crust and plays a role in heavy metal alleviation in plants by different mechanisms (Ma et al., 2008; Greger et al., 2016). One mechanism of Cd detoxification is the reduction of $\mathrm{Cd}$ uptake into the plant (Treder and Cieslinski, 2005). Also, Si reduces the translocation of $\mathrm{Cd}$ from roots to shoots and thus, prevents the adverse effect of $\mathrm{Cd}$ on photosynthetic machinery and grains (Greger and Landberg, 2008; Zhang et al., 2008). However, Cd in high concentration is also trapped in roots through vacuolar sequestrations (Greger et al., 2016), leading to decreased Cd translocation in aerial parts of the plants (Lindberg et al., 2007; Liu et al., 2013). Phytochelatins (PCs) and metallothioneins (MTs) may bind to $\mathrm{Cd}$ before transporting the complexes into the vacuole or out of the cell by ATP-binding cassette transporters in few plants (Cobbett, 2000; Jasinski et al., 2003). PCs are formed from glutathione by the induction of PCS1 gene (Semane et al., 2007). Further, MTs are involved in detoxifying cytosolic environment of the cell from Cd toxicity (Cobbett and Goldsbrough, 2002; DalCorso et al., 2010).

The Cd is taken up into the cell via carriers, such as lowaffinity cation transporters and Fe-regulated transporters in plants (Lindberg et al., 2004; Takahashi et al., 2011). Among the Fe transporters, IRTs and NRAMPs have been reported to take up Cd as well as Fe (Curie et al., 2000; Nakanishi et al., 2006). IRT1 is essential for root Fe uptake in response to Fe deficiency but it also accepts $\mathrm{Cd}$ as a substrate and is involved in the root-toshoot transport of Cd (Rogers et al., 2000). In a transgenic study, elimination of NRAMP5 transporter reduces Cd uptake in rice (Ishikawa et al., 2012). ). Additionally, the ferric chelate reductase (FRO) gene may perform key functions in Fe acquisition in plants (Ling et al., 2002). Barcelo et al. (1993) reported the inhibition of Fe translocation when bean plants were exposed to chromium (Cr) in nutrient solutions. Also, $\mathrm{Cr}$ affects Fe uptake in dicots either by inhibiting the reduction of $\mathrm{Fe}(\mathrm{III})$ to $\mathrm{Fe}(\mathrm{II})$ or by competing with $\mathrm{Fe}$ (II) at the site of absorption (Shanker et al., 2005). In addition, IRT1 is induced in response to Fe-deficiency and is capable of transporting minerals and heavy metals (Vert et al., 2002). Further, organic acids such as citrate and malate are major chelators in both Strategy I and II plants, which bind Fe at the site of uptake and facilitate long-distance transport in plants (Abadia et al., 2002; Kabir et al., 2012). Therefore, regulation of Fe uptake has yet to be characterized in detail under Cd stress in plants.

Abiotic stresses generate excessive reactive oxygen species (ROS) which are relatively reactive compared with $\mathrm{O}_{2}$ and may lead to the unspecific oxidation of proteins and membrane lipids or may cause DNA injury (Bolwell et al., 2002; Schützendübel and Polle, 2002). In plants, the control of oxidative burst is achieved by antioxidative systems. These defense systems are composed of enzymatic scavengers, such as catalase (CAT), peroxidase $(\mathrm{POD})$, superoxide dismutase (SOD), glutathione reductase (GR), ascorbate peroxidase (APX) and antioxidant metabolites. Among these enzymes, SOD is the front line of defense against ROS, dismutating reactive $\mathrm{O}_{2}$ to an oxygen molecule and $\mathrm{H}_{2} \mathrm{O}_{2}$ (Irfan et al., 2014). Further, an increase in the cellular ROS is subsequently converted to $\mathrm{H}_{2} \mathrm{O}_{2}$ (Hung et al., 2005). $\mathrm{H}_{2} \mathrm{O}_{2}$ can be directly decomposed through CAT or $\mathrm{H}_{2} \mathrm{O}_{2}$ can also be removed via recurrent oxidation-reduction reactions promoted by glutathione (Schützendübel and Polle, 2002). Further, APX enzymes use ascorbate as an electron donor to catalyze the conversion of $\mathrm{H}_{2} \mathrm{O}_{2}$ into $\mathrm{H}_{2} \mathrm{O}$ (Caverzan et al., 2012). In addition, some metabolites (i.e., glutathione, cysteine, glycine, methionine, proline) play critical roles to alleviate the damage induced by metal stress (Sharma and Dietz, 2006; Kumar et al., 2014; Kabir, 2016). Glutathione and proline may also function as sources of reduced-S and $\mathrm{N}$ under stress (Anjum et al., 2014).

Although the role of $\mathrm{Si}$ in $\mathrm{Cd}$ alleviation is reported in popular crop species, the physiological and molecular basis of Si-mediated Cd tolerance in Alfalfa is still unknown. Moreover, exact mechanisms behind the beneficial role of Si might be species dependent, which should be clearly understood for the improvement of Alfalfa. Therefore, our aim was to investigate whether, how and where Si alleviates Cd toxicity in Alfalfa by morpho-physiological investigations. Further, a combination of molecular, enzymatic and metabolomics analysis was performed in roots to elucidate the mechanisms associated with $\mathrm{Si}$-mediated mitigation of Cd toxicity in Alfalfa.

\section{MATERIALS AND METHODS}

\section{Plant Cultivation}

We used Alfalfa var. Longdong (popularly known as drought tolerant) since this cultivar is efficient in utilizing Si. Firstly, seeds were disinfected by superficial treatment with $95 \%(\mathrm{v} / \mathrm{v})$ ethanol for $10 \mathrm{~min}$ before germination. Only uniform seedlings were transferred to the solution culture (Hoagland and Arnon, $1950)$ containing the following nutrient concentrations $(\mu \mathrm{M})$ : $\mathrm{KNO}_{3}$ (16000), $\mathrm{Ca}\left(\mathrm{NO}_{3}\right)_{2} .4 \mathrm{H}_{2} \mathrm{O}$ (6000), $\mathrm{NH}_{4} \mathrm{H}_{2} \mathrm{PO}_{4}$ (4000), $\mathrm{MgSO}_{4} .7 \mathrm{H}_{2} \mathrm{O}$ (2000), $\mathrm{KCl}$ (50), $\mathrm{H}_{3} \mathrm{BO}_{3}$ (25), Fe-EDTA (25), $\mathrm{MnSO}_{4} \cdot 4 \mathrm{H}_{2} \mathrm{O}$ (2), $\mathrm{ZnSO}_{4}$ (2), $\mathrm{Na}_{2} \mathrm{MoO}_{4} \cdot 2 \mathrm{H}_{2} \mathrm{O}$ (0.5), and $\mathrm{CuSO}_{4} .5 \mathrm{H}_{2} \mathrm{O}(0.5)$. The nutrient medium was treated with 0 or $1 \mathrm{mM} \mathrm{CdCl}_{2}$ and 0 or $1 \mathrm{mM} \mathrm{K}_{2} \mathrm{SiO}_{3}$ as previously described (Greger et al., 2016). The $\mathrm{pH}$ of the nutrient media was adjusted to 6.0 by using $\mathrm{NaOH}$ or $\mathrm{HCl}$. The plants were harvested for analysis after treatment for 7 days. The nutrient solutions were continuously aerated and the growth chamber was strictly maintained under $10 \mathrm{~h}$ light and $14 \mathrm{~h}$ dark (550-560 $\mu \mathrm{mol} \mathrm{s}^{-1}$ per $\mu A)$.

\section{Measurement of Morphological Features and Chlorophyll Concentration}

Morphological growth parameters, such as root length, root dry weight, shoot height, shoot dry weight were measured on 1-weekold plants. The roots and leaves of the plants were separated manually and then dried in an oven at $80^{\circ} \mathrm{C}$ for 2 days before taking the dry weight. Total chlorophyll concentration (a and b) 
of leaves was determined as previously described (Lichtenthaler and Wellburn, 1985). Firstly, the leaf was weighed and placed in $95 \%$ acetone in a $5 \mathrm{~mL}$ falcon tube. The leaf sample was then ground with mortar-pestle and centrifuged at $12000 \mathrm{~g}$ for $10 \mathrm{~min}$. The absorbance of the separated supernatant was read at $662 \mathrm{~nm}$ (chlorophyll a) and $646 \mathrm{~nm}$ (chlorophyll b) on a spectrophotometer (UV-1650PC, Shimadzu). The amount of these pigments was calculated based on the formula given by Lichtenthaler and Wellburn (1985).

\section{Determination of $\mathrm{Cd}$ and Fe by AAS (Atomic Absorption Spectroscopy)}

Harvested roots and shoots were washed with $\mathrm{CaSO}_{4}$ and deionized water before drying in an oven at $80^{\circ} \mathrm{C}$ for 3 days. The dried samples were then digested in $3 \mathrm{~mL} \mathrm{HNO}_{3}$ before heating at $75^{\circ} \mathrm{C}$ for $10 \mathrm{~min}$. Further, $1 \mathrm{~mL}$ of $\mathrm{H}_{2} \mathrm{O}_{2}$ was added to each vessel through the ventilation hole and then heated at $109^{\circ} \mathrm{C}$ for $15 \mathrm{~min}$. The samples were then analyzed for $\mathrm{Cd}$ and $\mathrm{Fe}$ concentrations by Flame atomic absorption spectroscopy (AAS) outfitted with the ASC-6100 autosampler and air-acetylene atomization gas mixture system (Model No. AA-6800, Shimadzu). Standard solutions of $\mathrm{Cd}$ and $\mathrm{Fe}$ were prepared separately from their respective concentrations of stock solutions to cover the optimum absorbance ranges for the standard calibration curve.

\section{Determination of Total Soluble Proteins}

Total soluble proteins were extracted from roots and shoots as previously described (Guy et al., 1992) with some modifications. The samples were homogenized with a chilled mortar and pestle in buffer containing ice-cold $50 \mathrm{mM}$ Tris- $\mathrm{HCl}, \mathrm{pH} 7.5 ; 2 \mathrm{mM}$ EDTA and $0.04 \%(\mathrm{v} / \mathrm{v}) 2$-mercaptoethanol. The homogenate was centrifuged at $12000 \mathrm{~g}$ for $30 \mathrm{~min}$ at room temperature and the supernatant was then transferred $(100 \mu \mathrm{l})$ to glass cuvette containing $1 \mathrm{ml}$ of Coomassie Brilliant Blue G 250 (CBB). The absorbance was recorded at $595 \mathrm{~nm}$ and the concentration of total soluble protein was calculated using the calibration curve of Bovine serum albumin (BSA).

\section{Measurement of Electrolyte Leakage}

Electrolyte leakage (EL) was measured in roots and shoots using an electrical conductivity meter (Lutts et al., 1996). Seedling samples were washed with deionized water to remove surface contamination, weighed and placed in individual vials containing $20 \mathrm{~mL}$ of deionized water. Samples were then incubated at $25^{\circ} \mathrm{C}$ on a shaker $(100 \mathrm{rpm})$ for $2 \mathrm{~h}$. The electrical conductivity of the solution was then read after incubation.

\section{Determination of Si Concentration}

Roots and leaves were washed with $\mathrm{CaSO}_{4}$ and deionized water before grinding in mortar-pestle. The samples were then centrifuged at $12000 \mathrm{~g}$ for $5 \mathrm{~min}$ and supernatant was transferred to $10 \%$ ammonium molybdate. Afterward, $10 \%$ oxalic acid was added to the sample mixture to form a silico-molybdate complex. Further, $0.5 \%$ ascorbic acid was added to the mixture and kept for $20 \mathrm{~min}$ at room temperature until blue color is formed. The absorbance of the reaction mixture was then measured at $660 \mathrm{~nm}$ in a UV spectrophotometer.

\section{Analysis of Plant Metabolites by HPLC (High-Performance Liquid Chromatography)}

Plant metabolites were analyzed in roots harvested from 1-weekold plants by HPLC (Binary Gradient HPLC System, Waters Corporation, Milford, MA, USA) with Empower2 ${ }^{\mathrm{TM}}$ software as previously described with some modifications (Kabir et al., 2015). The HPLC systems comprised a Waters 515 HPLC pump and Waters In-line degasser AF. For compound separation, a C18 reverse phase-HPLC column (particle size: $5 \mu \mathrm{m}$, pore size: 300 A, pH Range: 1.5-10, Dimension: $250 \mathrm{~mm} \times 10 \mathrm{~mm}$ ) was attached. In mobile phase, buffer $\mathrm{A}$ (water and $0.1 \%$ TFA) and buffer B ( $80 \%$ acetonitrile and $0.1 \%$ TFA) were used at the gradient of: 1-24 min 100\% A, 25-34 min 100\% B and 35$40 \mathrm{~min} 100 \% \mathrm{~A}$. Standards and sample extracts were diluted $(100 \times)$ and subsequently filtered using $0.22 \mu \mathrm{m}$ Minisart Syringe Filters (Sartorius Stedim Biotech, Germany) before injection. PC were then detected with a Waters 2489 dual absorbance detector (Waters Corporation, Milford, MA, USA) at 280 and $360 \mathrm{~nm}$. For PC analysis, the peak was detected with Thlaspi arvensis in comparison with the retention times. GSH-equivalents of each PC were further used for PC quantification (Lindberg et al., 2007).

\section{Fe Chelate Reductase Activity}

$\mathrm{Fe}$ (III)-reductase activity was measured in roots and shoots using ferrozine [3-(2-pyridyl)-5, 6-diphenyl-1,2, 4-triazine sulfonate] as previously described (Kabir et al., 2015). Washed root tips were cut and placed in a beaker filled with ice water. About $0.1 \mathrm{~g}$ of tissue was soaked in $1 \mathrm{mM}$ EDTA for $5 \mathrm{~min}$ to eliminate apoplastic $\mathrm{Fe}$ and washed three times with distilled water to reduce excess EDTA. The roots were then transferred to $50 \mathrm{~mL}$ assay solution containing 0.10 mM MES- $\mathrm{NaOH}$ (pH 5.5), $0.5 \mathrm{mM}$ $\mathrm{CaSO}_{4}, 100$ mM Fe(III) EDTA, and $300 \mathrm{mM}$ ferrozine. Samples and control tubes were incubated for $1 \mathrm{~h}$ in a shaking water bath at $14,000 \mathrm{rpm}$ at $23^{\circ} \mathrm{C}$ in the dark. After incubation, a $1 \mathrm{~mL}$ aliquot from each tube was transferred into a cuvette and the absorbance was measured with a spectrophotometer (UV-1650PC, Shimadzu) at $562 \mathrm{~nm}$ wavelength. Reduced Fe $[\mathrm{Fe}(\mathrm{II})]$ was calculated with the use of an extinction coefficient of $25,200 \mathrm{M}^{-1} \mathrm{~cm}^{-1}$.

\section{RNA Isolation and Quantitative Real-Time PCR}

Expression analysis of Actin, MsPCS1, MsMT2, MsIRT1, MsNRAMP1, and MsFRO1 was performed by quantitative qRTPCR (reverse transcription PCR) in roots of 1-week-old plants. Briefly, tissues (50-100 mg) were ground with a mortar and pestle to a fine powder in liquid nitrogen. Afterward, total RNA was isolated according to the protocol supplied by SV Total RNA Isolation System (cat. no. Z3100), Promega Corporation, USA. The integrity of isolated RNA was then checked by denaturing agarose gel electrophoresis and quantified by NanoDrop 2000 UV-Vis Spectrophotometer. The first-strand cDNA was then 
synthesized by using GoScript ${ }^{\mathrm{TM}}$ Reverse Transcription System (Cat no. A5001), Promega Corporation, United States. Before real-time analysis, the cDNA samples were treated with RNase to eliminate RNA contamination. Real-time PCR was performed in triplicate using the Eco ${ }^{\mathrm{TM}}$ real-time PCR system (Illumina, United States) using GoTaq $^{\circledR}$ qPCR Master Mix (Promega, USA) and gene specific primers designed from the available gene sequences of Medicago sativa or Medicago truncatula (Supplementary Table S1). All primers were used to perform BLASTN searches with Arabidopsis genome database to confirm that they would specifically amplify the gene of interest. Expression data set was normalized with Actin as an internal control (Eco Software v4.0.7.0). The real-time PCR program used was as follows: $3 \mathrm{~min}$ at $95^{\circ} \mathrm{C}, 40$ cycles of $30 \mathrm{~s}$ at $94^{\circ} \mathrm{C}, 15 \mathrm{~s}$ at $58^{\circ} \mathrm{C}$ and $30 \mathrm{~s}$ at $72^{\circ} \mathrm{C}$.

\section{Enzymatic Analysis}

Catalase, APX, POD, SOD and GR enzymes were extracted in roots of on 1-week-old plants as previously described with slight modifications (Goud and Kachole, 2012). Briefly, $100 \mathrm{mg}$ of root tissue was ground in $5 \mathrm{~mL}$ phosphate buffer $(100 \mathrm{mM})$ and centrifuged at $12000 \mathrm{~g}$ for $10 \mathrm{~min}$ to separate supernatant. For CAT analysis, the reaction mixture $(2 \mathrm{~mL})$ contained $100 \mathrm{mM}$ potassium phosphate buffer $(\mathrm{pH} 7.0), 6 \% \mathrm{H}_{2} \mathrm{O}_{2}$ and root extract. After adding the root extract, the decrease in absorbance was recorded at $240 \mathrm{~nm}$ (extinction coefficient of $0.036 \mathrm{mM}^{-1} \mathrm{~cm}^{-1}$ ) using a UV spectrophotometer at $30 \mathrm{~s}$ intervals up to $1 \mathrm{~min}$. APX was analyzed in a reaction mixture containing $50 \mathrm{mM}$ potassium phosphate buffer $(\mathrm{pH} 7.0), 0.5 \mathrm{mM}$ ascorbic acid, $0.1 \mathrm{mM}$ EDTA, $0.1 \mathrm{mM} \mathrm{H}_{2} \mathrm{O}_{2}$, and $0.1 \mathrm{ml}$ extract. The specific activity of the enzyme was calculated using extinction coefficient of $2.8 \mathrm{mM}^{-1} \mathrm{~cm}^{-1}$ based on absorbance at $290 \mathrm{~nm}$ (Almeselmani et al., 2006). In case of POD, the reaction mixture $(2 \mathrm{~mL})$ contained $100 \mathrm{mM}$ potassium phosphate buffer ( $\mathrm{pH}$ 6.5), $0.05 \mathrm{M}$ pyrogallol, $200 \mathrm{mM} \mathrm{H} \mathrm{O}_{2}$ and $100 \mu \mathrm{l}$ root extract. Similarly, the changes in absorbance were measured at $430 \mathrm{~nm}$ (extinction coefficient $12 \mathrm{mM}^{-1} \mathrm{~cm}^{-1}$ ) in a spectrophotometer from $30 \mathrm{~s} \mathrm{up}$ to $1.5 \mathrm{~min}$. Furthermore, SOD assay mixture contained $50 \mathrm{mM}$ sodium carbonate/bicarbonate buffer ( $\mathrm{pH}$ 9.8), 0.1 mM EDTA, $0.6 \mathrm{mM}$ epinephrine and enzyme (Sun and Zigman, 1978). Once epinephrine is added, adrenochrome formation was then monitored for $4 \mathrm{~min}$ at $475 \mathrm{~nm}$ in a UV-Vis spectrophotometer. Lastly, $100 \mu \mathrm{l}$ of root extract was added to the assay mixture containing $1 \mathrm{~mL}$ of $0.2 \mathrm{M}$ phosphate buffer ( $\mathrm{pH}$ 7.0) with $1 \mathrm{mM}$ EDTA, $20 \mathrm{mM}$ oxidized glutathione (GSSG) and $2 \mathrm{mM} \mathrm{NADPH}$ for GR analysis. Oxidation of NADPH by GR was then recorded at $340 \mathrm{~nm}$ (Halliwell and Foyer, 1978). The hydrogen peroxide $\left(\mathrm{H}_{2} \mathrm{O}_{2}\right)$ content was determined in roots and shoots as previously described (Alexieva et al., 2001). Briefly, tissues were crushed in $0.1 \%$ trichloroacetic acid (TCA) and centrifuged at 10, $000 \mathrm{~g}$ for $15 \mathrm{~min}$. The supernatant was kept in dark for $1 \mathrm{~h}$ before mixing with phosphate buffer $(10 \mathrm{mM}, \mathrm{pH} 7.0)$ and potassium iodide (M). The absorbance of the mixture was recorded at $390 \mathrm{~nm}$.

\section{Statistical Analysis}

All experiments were performed in completely randomized block design and having at least three independent replications for each sample. Statistical significance for each group of data was set at $P \leq 0.05$ by ANOVA one-way followed by Duncan's Multiple Range Test (DMRT) using SPSS Statistics 20 Software. Further, the graphical presentation was prepared using GraphPad Prism 6.

\section{RESULTS}

\section{Morpho-Physiological Features}

Root length, root dry weight, shoot height, shoot dry weight, and total chlorophyll concentration $(a$ and $b)$ significantly $(P<0.05)$ decreased due to $\mathrm{Cd}$ stress compared with non-treated controls (Table 1; Figure 1). However, these parameters significantly increased due to Si application in combination with Cd treatment compared with Cd-stressed plants. Si supplementation in nonstressed plants caused an adverse effect on root length and shoot dry weight compared to that observed for Cd-stressed plants but showed similar root dry weight and chlorophyll concentration to that of control plants (Table 1). However, results showed a nonsignificant change in morphological features between untreated controls and Si-treated Cd-stressed plants (Table 1).

\section{$\mathrm{Cd}, \mathrm{Fe}$, and Si Contents in Roots and Shoots}

Cadmium and Fe contents increased in the whole plant under Cd stress compared with non-treated controls, showing the higher amount in roots than in shoots (Figure 2A). Supplementation with $\mathrm{Si}$ along with $\mathrm{Cd}$ significantly decreased the accumulation of $\mathrm{Cd}$ and $\mathrm{Fe}$ in both roots and shoots compared with the other three (i.e., $\mathrm{Cd}^{-}, \mathrm{Cd}^{+}, \mathrm{Cd}_{-} \mathrm{Si}^{+}$) treatments (Figures $2 \mathrm{~A}, \mathbf{B}$ ). Plant showed lower Si concentration in roots when plants were grown without Si treatment compared with Si-treated plants grown with or without Cd. Further, Si concentration significantly increased in roots when plants were treated with $\mathrm{Cd}$ along

TABLE 1 | Morpho-physiological features of Alfalfa after cultivation for 7 days in nutrient medium with or without Cd and Si.

\begin{tabular}{|c|c|c|c|c|c|}
\hline Treatments & Root length (cm) & Root dry weight (mg) & Shoot height $(\mathrm{cm})$ & Shoot dry weight (mg) & Total chl $a$ and $b\left(\mathrm{mg}^{-1} \mathrm{FW}\right)$ \\
\hline $\mathrm{Cd}^{-}$ & $5.1 \pm 0.17^{b}$ & $8.6 \pm 0.57^{b}$ & $5.3 \pm 0.10^{b}$ & $2.1 \pm 0.30^{b}$ & $76.5 \pm 7.4^{b}$ \\
\hline $\mathrm{Cd}^{+}$ & $1.7 \pm 0.45^{\mathrm{a}}$ & $4.5 \pm 0.50^{a}$ & $3.6 \pm 0.30^{a}$ & $1.2 \pm 0.15^{\mathrm{a}}$ & $40.2 \pm 9.8^{\mathrm{a}}$ \\
\hline $\mathrm{Cd}^{+} \mathrm{Si}^{+}$ & $4.5 \pm 0.70^{b}$ & $7.5 \pm 0.50^{\mathrm{b}}$ & $4.6 \pm 0.65^{b}$ & $1.9 \pm 0.15^{b}$ & $80.6 \pm 14.3^{b}$ \\
\hline $\mathrm{Cd}^{-} \mathrm{Si}^{+}$ & $1.9 \pm 0.60^{a}$ & $6.6 \pm 2.08 a^{b}$ & $3.1 \pm 0.64^{a}$ & $1.7 \pm 0.56^{a b}$ & $79.4 \pm 18.7^{b}$ \\
\hline
\end{tabular}

Different letters in each column indicate significant differences between mean $\pm S D$ of treatments $(n=3)$ at a $P<0.05$ significance level. 


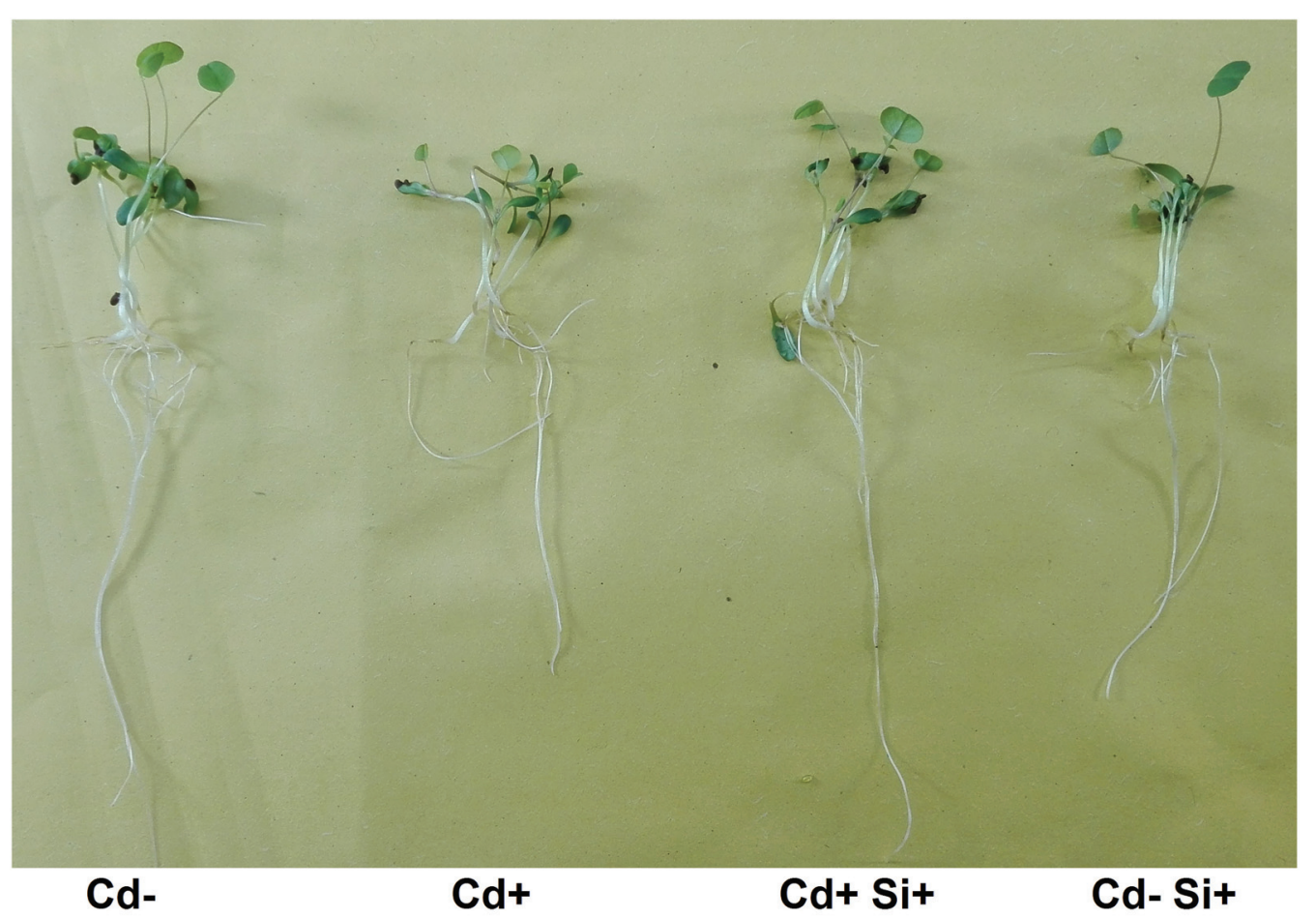

FIGURE 1 | Phenotypes of 7-days-old Alfalfa plants grown under different growth conditions of $\mathrm{Cd}$ and $\mathrm{Si}$.

with Si compared with the plants grown with or without $\mathrm{Cd}$ under hydroponic conditions (Figure 2C). Plants treated by $\mathrm{Si}$ without Cd showed significantly decreased Si concentration in roots compared to the plants grown under dual treatment of $\mathrm{Si}$ and $\mathrm{Cd}$. In shoots, Si concentration considerably increased when plants were grown under Si supplementation with or without Cd compared to non-treated control and Cd-stressed plants (Figure 2C).

\section{Determination of Total Soluble Protein Content, Electrolyte Leakage, Fe Chelate Reductase Activity}

Cadmium stress caused a significant decrease in total protein content in both roots and leaves compared to control plants. However, application of Si along with Cd significantly increased the protein content in both tissues compared with Cd-stressed plants. When treated solely with Si on controls, plants showed protein content similar to that of the plants grown with $\mathrm{Si}$ and Cd supplementation (Figure 3A). The EL significantly increased in both roots and shoots under $\mathrm{Cd}$ stress compared with control plants $\left(\mathrm{Cd}^{-}\right)$. However, the EL significantly decreased in both tissues due to $\mathrm{Si}$ along with $\mathrm{Cd}$ treatments compared with Cd-stressed Alfalfa (Figure 3B). Si applied solely in nontreated plants showed similar EL to that of plants treated with $\mathrm{Cd}$ and $\mathrm{Si}$ along with $\mathrm{Cd}$ in roots and shoots, respectively (Figure 3B).

Cadmium toxicity caused a significant increase in Fe-chelate reductase activity in both roots and shoots in comparison with control plants (Figure 4). However, Si supplementation along with $\mathrm{Cd}$ showed a significant decrease in Fe-chelate reductase activity compared with Cd-stressed plants (Figure 4). Si applied solely to non-treated plants showed similar Fe-chelate reductase activity in roots to that of controls and plants treated with Si and $\mathrm{Cd}$. However, Fe-chelate reductase activity significantly increased in shoots compared to controls but showed similar activity to that of plants grown under both $\mathrm{Si}$ and $\mathrm{Cd}$ supplementations (Figure 4).

\section{HPLC Analysis in Roots}

In this study, phytochelatin showed no significant changes in roots among the treatments in Alfalfa plants (Table 2). Further, citrate and malate concentrations significantly decreased due to Cd stress compared with non-treated controls. However, Si application to Cd-stressed plants showed a significant increase in citrate and malate concentrations in roots compared with the plants grown under Cd stress. Si applied solely to control plants showed similar citrate and malate levels to that of control plants (Table 2).

\section{Expression of Genes in Roots}

Quantitative real-time PCR analysis showed no significant changes in the expression of two metal chelators (MsPCS1 and MsMT2) in roots of Alfalfa among the treatments (Figure 5). However, three Fe-related genes, MsIRT1, MsNramp1, and MsFRO1 significantly upregulated in roots of Alfalfa plants under Cd stress compared with control plants. Further, expression of 

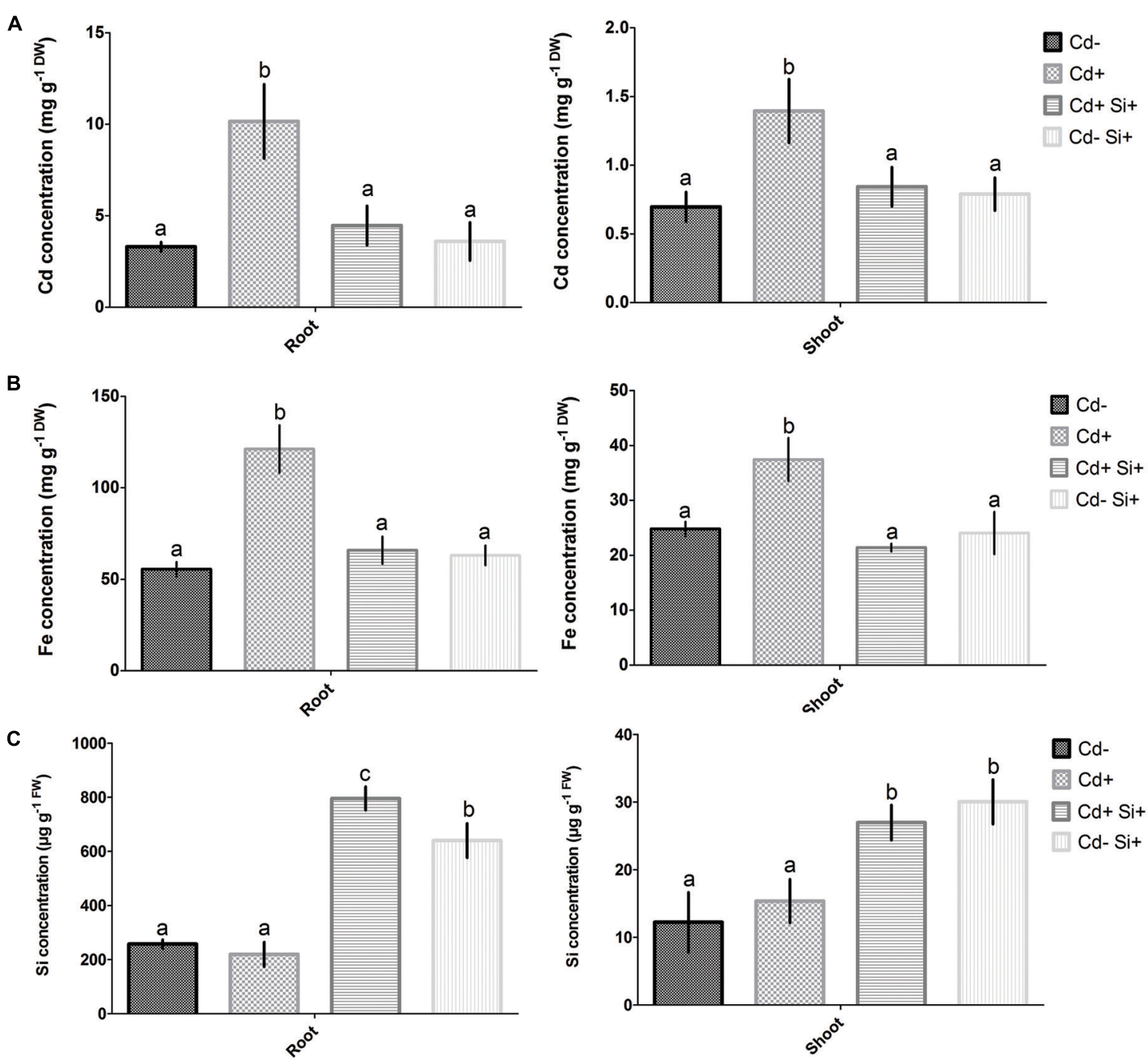

FIGURE 2 | Concentrations of $\mathrm{Cd}$ (A), Fe (B), and $\mathrm{Si}$ (C) in roots and shoots of 7-days-old Alfalfa plants grown under different growth conditions of Cd and Si. Different letters in each column indicate significant differences between mean \pm SD of treatments $(n=3)$ at a $P<0.05$ significance level.

these genes significantly decreased when plants were treated with Si along with Cd (Figure 5). Si applied to non-treated plants showed similar expression pattern for these Fe-related genes to that of control plants (Figure 5).

\section{Enzymatic Changes in Roots}

Enzymatic activity of CAT, APX, and SOD significantly decreased due to $\mathrm{Cd}$ stress compared with controls in roots of Alfalfa. However, application of Si along with Cd showed a significant increase in CAT, APX, and SOD activities compared with Cdstressed plants (Table 3). Si applied solely to non-treated plants showed similar activities CAT and SOD to that of control plants. Further, POD and GR activities showed no significant changes in roots of Alfalfa among the treatments. Results also demonstrated that $\mathrm{H}_{2} \mathrm{O}_{2}$ content significantly increased due to $\mathrm{Cd}$ stress compared with controls in roots. However, application of $\mathrm{Si}$ with or without $\mathrm{Cd}$ showed a significant decrease in $\mathrm{H}_{2} \mathrm{O}_{2}$ content compared with Cd-stressed plants (Table 3).

\section{Changes in Antioxidant Metabolites}

We also studied the changes in some key metabolites having antioxidant properties. It was found that glutathione and cysteine showed no significant changes in roots of Alfalfa plants subjected to different treatments of $\mathrm{Cd}$ and $\mathrm{Si}$ (Table 4). However, Cd stress caused a significant decrease in methionine compared with controls but showed a significant increase when plants were treated with $\mathrm{Cd}$ and $\mathrm{Si}$. Further, the investigation showed no significant reduction in proline concentration in response to $\mathrm{Cd}$ stress, application of $\mathrm{Si}$ along with $\mathrm{Cd}$ significantly increased proline concentration in roots of Alfalfa. Application of Si to control plants showed similar proline level to that of controls (Table 4). 

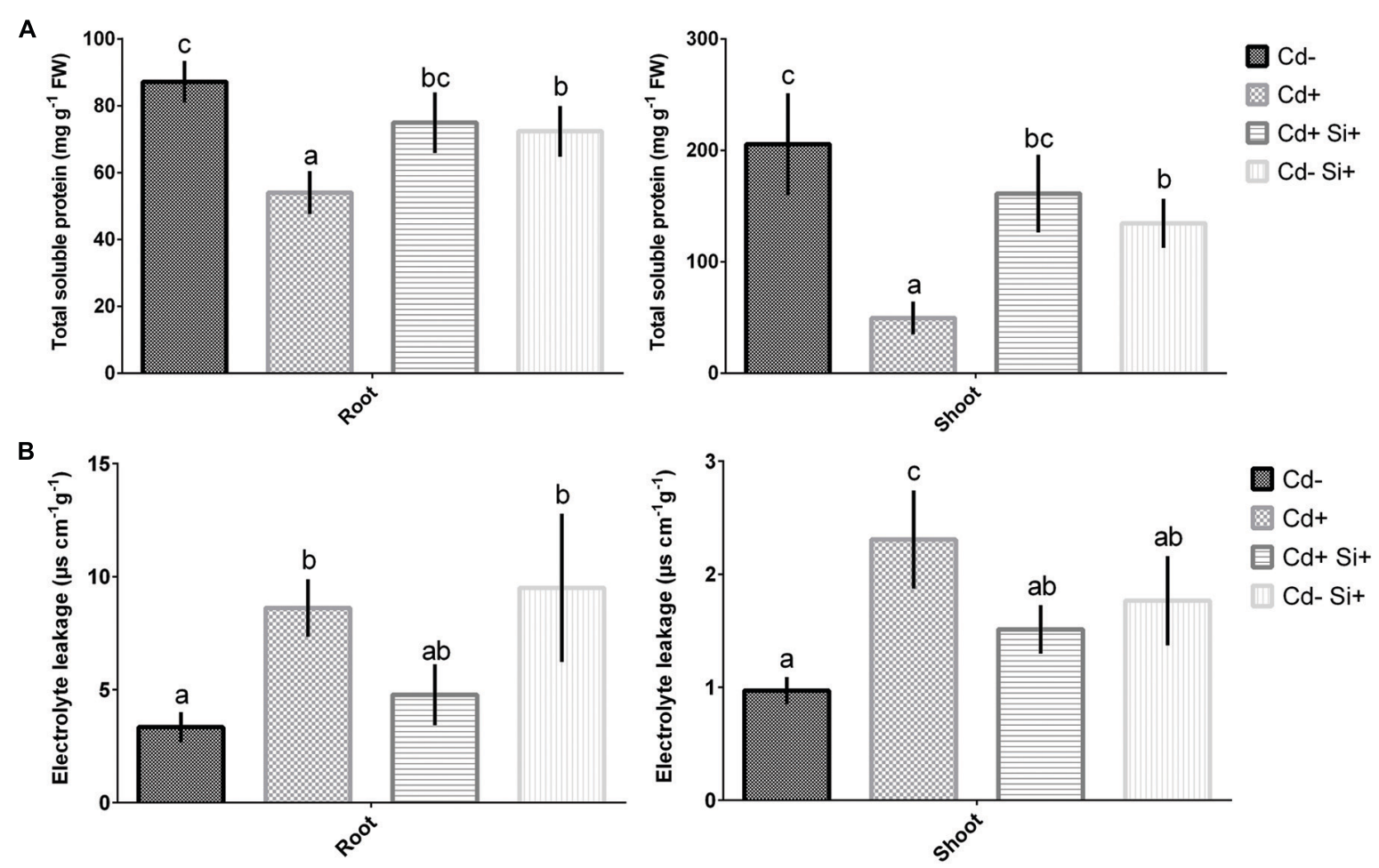

FIGURE 3 | Total protein content (A) and electrolyte leakage (B) in roots and shoots of Alfalfa plants grown under different growth conditions of Cd and Si. Different letters in each column indicate significant differences between mean \pm SD of treatments $(n=3)$ at a $P<0.05$ significance level.
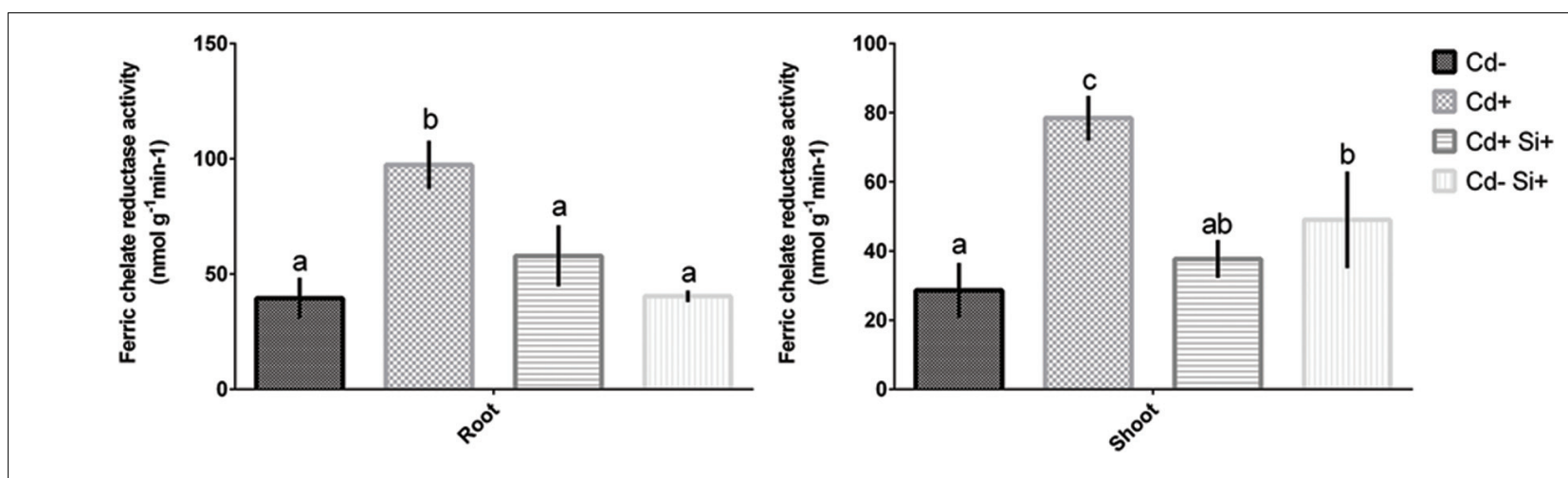

FIGURE 4 | Fe chelate reductase activity in roots and shoots of 7-days-old Alfalfa plants grown under different growth conditions of Cd and Si. Different letters in each column indicate significant differences between mean \pm SD of treatments $(n=3)$ at a $P<0.05$ significance level.

\section{DISCUSSION}

\section{Role of Si Restoring Morphological Features}

In the present study, Si supplementation under $\mathrm{Cd}$ showed significant improvement in root and shoot growth parameters along with total chlorophyll content in Alfalfa. Also, application of $\mathrm{Si}$ in Cd-treated plants restored the total protein content in both roots and shoots compared with Cd-stressed plants. The role of $\mathrm{Si}$ increasing total soluble protein under drought stress is associated with the reduction of free radicals and ROS regeneration (Gong et al., 2005). Furthermore, application of Si in Cd-stressed plants diminished the EL in both roots and shoots. It indicates that exogenous Si might provide membrane stability in Cd-stressed Alfalfa plants. In a similar study, lead $(\mathrm{Pb})$ stress induced a significant increase in the membrane injury but $\mathrm{Si}$ application noticeably eliminated EL in cotton plants (Bharwana et al., 2013). Although differences were not statistically significant, Si application under Cd stress did not completely restore morphological features back to that observed for untreated controls. This could be due to the concentration of $\mathrm{Cd}$ and $\mathrm{Si}$ used and can be optimized depending on the 
TABLE 2 | Concentrations $\left(\mu \mathrm{g}^{-1} \mathrm{FW}\right)$ of total phytochelatin, citrate and malate in roots of 7-days-old Alfalfa plants grown under different growth conditions of $\mathrm{Cd}$ and $\mathrm{Si}$.

\begin{tabular}{llll}
\hline Treatments & Phytochelatin & Citrate & Malate \\
\hline $\mathrm{Cd}^{-}$ & $1.54 \pm 0.37^{\mathrm{a}}$ & $1.33 \pm 0.17^{\mathrm{a}}$ & $1.24 \pm 0.12^{\mathrm{a}}$ \\
$\mathrm{Cd}^{+}$ & $1.91 \pm 0.70^{\mathrm{a}}$ & $2.94 \pm 0.73^{\mathrm{b}}$ & $3.95 \pm 0.47^{\mathrm{b}}$ \\
$\mathrm{Cd}^{+} \mathrm{Si}^{+}$ & $1.86 \pm 0.21^{\mathrm{a}}$ & $1.06 \pm 0.08^{\mathrm{a}}$ & $0.85 \pm 0.13^{\mathrm{a}}$ \\
$\mathrm{Cd}^{-} \mathrm{Si}^{+}$ & $1.91 \pm 0.04^{\mathrm{a}}$ & $0.94 \pm 0.05^{\mathrm{a}}$ & $1.99 \pm 1.99^{\mathrm{a}}$
\end{tabular}

Different letters in each column indicate significant differences between mean $\pm S D$ of treatments $(n=3)$ at a $P<0.05$ significance level.

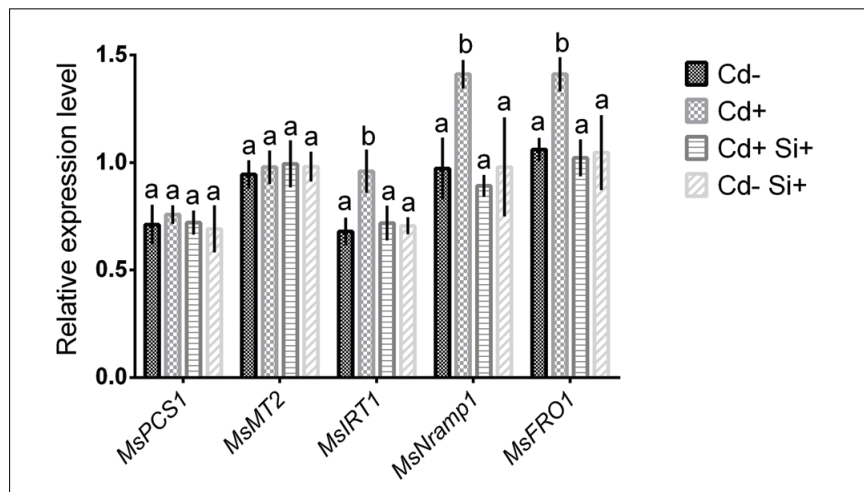

FIGURE 5 | Quantitative expression analysis of MsPCS1, MsMT2, MsIRT1, MsNRAMP1, MsFRO1 transcripts in roots of Alfalfa plants grown under different growth conditions for 7-days. Different letters in each column indicate significant differences between mean $\pm S D$ of treatments $(n=3)$ at a $P<0.05$ significance level.

severity of stress involved. We also observed that Si was able to withstand the adverse effect of $\mathrm{Cd}$ on leaf expansion and stem elongation in Alfalfa. It might coincide with the role of silicon increasing soluble protein content and maintaining chlorophyll concentrations in shoots (Zhu et al., 2004; Farooq et al., 2013). Altogether, our findings support that Si can restore the damages and significantly improved the growth parameters provoked by Cd stress in Alfalfa var. Longdong plants due to its efficiency in utilizing exogenous Si. Genotypic variation in $\mathrm{Cd}$ accumulation and tolerance is reported in many plant species (Metwally et al., 2004; Yan et al., 2010; Pourghasemiana et al., 2013). Therefore, Si-mediated alleviation of Cd toxicity may behave differently in other cultivars of Alfalfa.

Atomic absorption spectroscopy data further showed that dual application of $\mathrm{Si}$ and $\mathrm{Cd}$ showed a reduction of $\mathrm{Cd}$ concentration to its normal level in both roots and shoots. It indicates that $\mathrm{Si}$ inhibits $\mathrm{Cd}$ uptake in roots and subsequently reduces the translocation of Cd into the shoots of Alfalfa plants. Similarly, Si-mediated reduction of Cd uptake was also reported in roots of cucumber ( $\mathrm{Wu}$ et al., 2015). In the present study, we also observed higher accumulation of Fe in roots and shoots due to $\mathrm{Cd}$ stress. Interestingly, Si supplementation under Cd stress showed a significant decrease in Fe concentrations in both roots and shoots, being consistent with $\mathrm{Cd}$ concentration. These findings support that inhibition of Cd uptake in roots of Alfalfa plants is tightly regulated with $\mathrm{Fe}$ transport under Si supplementation. In the light of Si concentration in roots and shoots, it is evident that Alfalfa plants require more exogenous $\mathrm{Si}$ under $\mathrm{Cd}$ stress to withstand its toxicity. In this study, it was also noticed that exogenous Si applied to non-treated plants showed a slight reduction in root parameters. It may be possible that exogenous Si when not used by plants for Cd alleviation might hamper metabolism. Taken together, our findings indicate that alleviation of Cd toxicity in Alfalfa plants is largely dependent on the regulation of $\mathrm{Cd}$ and $\mathrm{Fe}$ uptake in root systems.

\section{Biochemical and Molecular Mechanisms Associated with Cd Detoxification}

In the light of morpho-physiological observations, the mechanistic basis for $\mathrm{Cd}$ toxicity tolerance through $\mathrm{Si}$ supplementation was further investigated in roots of Alfalfa plants. We initially performed PC analysis and two candidate genes (MsPCS1, MsMT2) responsible for vacuolar sequestration in roots. HPLC analysis showed no significant changes in $\mathrm{PC}$ accumulation in roots under dual treatment of $\mathrm{Si}$ and $\mathrm{Cd}$ compared with control and Cd-stressed Alfalfa plants. Being consistent with PC accumulation, expression of MsPCS1 and MsMT2 showed no significant changes in roots of Alfalfa due to Si effect. Induction of PC and MT is involved in vacuolar sequestration of heavy metal is plants. However, Greger et al. (2016) suggested that the inhibition of Cd uptake in wheat closely associated with the increased $\mathrm{Cd}$ extrusion from the cells than PC accumulation. Our studies indicate that $\mathrm{Cd}$ detoxification in Alfalfa plants following Si application may not be associated with the change in metal sequestrations in roots. This observation is correlated with AAS data revealing no significant $\mathrm{Cd}$ accumulation in roots due to $\mathrm{Si}$ application. Therefore, it might be possible that effect of Si on Cd-stressed Alfalfa is dependent on the inhibition of metal transporters in root systems.

As there are no specific Cd transporters in plants, uptake of $\mathrm{Cd}$ is achieved by transporter genes located on plasma membranes (Morel et al., 2009). To characterize the Fe-chelating potential under Si supplementations in Alfalfa, we further studied the changes of Fe related genes (MsIRT1, OsNRAMP1, and MsFRO1) along with Fe-reductase activity in roots. Expression of these genes and Fe-reductase activity significantly decreased due to $\mathrm{Si}$ application under $\mathrm{Cd}$ stress in Alfalfa plants, indicating that regulation of $\mathrm{Fe}$ uptake and chelation plays a critical role in limiting Fe-mediated Cd accumulation in Alfalfa plants under Si supplementation. Fe-chelate reductase activity is known as an important biochemical mechanism regulating Fe availability in plant cells. FROs genes may be required for $\mathrm{Fe}$ distribution within aerial portions of the plant and/or may be involved in Fe transport mechanisms in the organelle (Jeong and Connolly, 2009). Changes of transcription factors belonging to several families demonstrate that responses of plants under Cd stress are very complex (Fusco et al., 2005; Weber et al., 2006). Transcription factors regulating genes involved in $\mathrm{Cd}$ detoxification following $\mathrm{Si}$ supplementation might provide interesting message to future researchers. Our data further showed a significant increase in two Fe chelators (citrate and malate) in roots due to $\mathrm{Cd}$ stress revealing that the chelation of 
TABLE 3 | Enzymatic activities in roots of Alfalfa after cultivation for 7 days in nutrient medium with or without Cd and Si.

\begin{tabular}{|c|c|c|c|c|c|c|}
\hline Treatments & $\begin{array}{l}\text { CAT } \min ^{-1}[(\mathrm{mg} \\
\left.\text { protein })^{-1}\right]\end{array}$ & $\begin{array}{l}\text { APX } \min ^{-1}[(\mathrm{mg} \\
\left.\text { protein })^{-1}\right]\end{array}$ & $\begin{array}{l}\text { POD } \min ^{-1}[(\mathrm{mg} \\
\left.\text { protein })^{-1}\right]\end{array}$ & $\begin{array}{l}\text { SOD [U.mg } \\
\text { protein] }\end{array}$ & $\begin{array}{c}\text { GR [nmol.NADH.min } \\
\left.\text { protein }^{-1}\right]\end{array}$ & $\begin{array}{c}\mathrm{H}_{2} \mathrm{O}_{2} \text { content } \mu \mathrm{mol} \\
\mathrm{g}^{-1} \mathrm{FW}\end{array}$ \\
\hline $\mathrm{Cd}^{-}$ & $1.07 \pm 2.26^{a}$ & $3.46 \pm 0.50^{a}$ & $0.20 \pm 0.03^{a}$ & $0.19 \pm 0.02^{b}$ & $0.51 \pm 0.38^{a}$ & $0.33 \pm 0.07^{a}$ \\
\hline $\mathrm{Cd}^{+}$ & $1.85 \pm 0.46^{b}$ & $1.45 \pm 0.32^{b}$ & $0.24 \pm 0.05^{a}$ & $0.09 \pm 0.03^{a}$ & $0.23 \pm 0.10^{a}$ & $2.94 \pm 0.79^{b}$ \\
\hline $\mathrm{Cd}^{+} \mathrm{Si}^{+}$ & $3.08 \pm 0.26^{c}$ & $3.82 \pm 0.80^{a}$ & $0.20 \pm 0.03^{a}$ & $0.19 \pm 0.03^{b}$ & $0.16 \pm 0.05^{a}$ & $1.10 \pm 0.24^{a}$ \\
\hline $\mathrm{Cd}^{-} \mathrm{Si}^{+}$ & $0.61 \pm 0.26^{a}$ & $3.94 \pm 1.21^{a}$ & $0.21 \pm 0.02^{a}$ & $0.13 \pm 0.01^{b}$ & $0.23 \pm 0.02^{a}$ & $0.78 \pm 0.13^{a}$ \\
\hline
\end{tabular}

Different letters in each column indicate significant differences between mean \pm SD of treatments $(n=3)$ at a $P<0.05$ significance level.

TABLE 4 | Concentrations $\left(\mu \mathrm{g}^{-1} \mathrm{FW}\right)$ of antioxidant metabolites in roots of 7-days-old Alfalfa plants grown under different growth conditions of $\mathrm{Cd}$ and $\mathrm{Si}$.

\begin{tabular}{lrllr}
\hline Treatments & Glutathione & Cysteine & Methionine & Proline \\
\hline $\mathrm{Cd}^{-}$ & $9.8 \pm 1.89^{\mathrm{a}}$ & $5.6 \pm 1.37^{\mathrm{a}}$ & $2.7 \pm 0.69^{\mathrm{b}}$ & $4.1 \pm 1.36^{\mathrm{a}}$ \\
$\mathrm{Cd}^{+}$ & $11.9 \pm 2.42^{\mathrm{a}}$ & $5.8 \pm 0.70^{\mathrm{a}}$ & $1.2 \pm 0.25^{\mathrm{a}}$ & $5.6 \pm 2.8^{\mathrm{a}}$ \\
$\mathrm{Cd}^{+} \mathrm{Si}^{+}$ & $11.3 \pm 3.12^{\mathrm{a}}$ & $5.1 \pm 0.73^{\mathrm{a}}$ & $6.8 \pm 0.59^{\mathrm{d}}$ & $12.3 \pm 2.3^{\mathrm{b}}$ \\
$\mathrm{Cd}^{-} \mathrm{Si}^{+}$ & $12.0 \pm 2.10^{\mathrm{a}}$ & $5.7 \pm 0.47^{\mathrm{a}}$ & $4.9 \pm 0.70^{\mathrm{c}}$ & $6.8 \pm 2.0^{\mathrm{a}}$ \\
\hline
\end{tabular}

Different letters in each column indicate significant differences between mean $\pm S D$ of treatments $(n=3)$ at a $P<0.05$ significance level.

Fe through the organic acids is associated with enhanced Fe as well as Cd uptake in Alfalfa. Interestingly, Si application to Cdstressed plants resulted in a decrease in both citrate and malate concentrations. It indicates that Si might indirectly decrease Cd accumulation through the inhibition of Fe chelation strategies in Alfalfa plants.

\section{Antioxidant Defense under Cd Stress}

We also analyzed antioxidant enzymes involved in antioxidant defense in plants under abiotic stress. Among these enzymes, CAT and SOD activities significantly increased in roots under Si supplementation in Cd-stressed Alfalfa plants. CAT is involved in the main defense mechanism against accumulation and toxicity of ROS and may play a fundamental role in decreasing $\mathrm{H}_{2} \mathrm{O}_{2}$ level in plant cells (Malar et al., 2014). SOD provides a front line defense under the metal-induced oxidative damage and catalyzes the conversion of the superoxide radical to molecular oxygen and $\mathrm{H}_{2} \mathrm{O}_{2}$ (Romero-Puertas et al., 2007; Irfan et al., 2014). In the present work, Alfalfa plants have a tendency to increase SOD activity under Cd stress, suggesting better efficiency in converting $\mathrm{O}_{2}$ to $\mathrm{H}_{2} \mathrm{O}_{2}$ following $\mathrm{Si}$ treatment. The higher CAT and SOD activities due to $\mathrm{Si}$ on Cd-stressed Alfalfa plants may be partially correlated with the 0decreased $\mathrm{H}_{2} \mathrm{O}_{2}$ concentrations in roots. CAT mainly occurs in peroxisomes and does not require a reductant for catalyzing a dismutation reaction (Sofo et al., 2015). Wu et al. (2015) also reported that the Si-mediated increases in antioxidant enzymes might be an adaptive response to counteract $\mathrm{Cd}$ stress in tomato. However, the increase of APX due to $\mathrm{Si}$ supplementation under $\mathrm{Cd}$ stress indicates that inhibition of $\mathrm{H}_{2} \mathrm{O}_{2}$ might be associated with its increased activity. APX is largely intracellular and involved in the control of cellular $\mathrm{H}_{2} \mathrm{O}_{2}$ levels in chloroplasts, cytosol, mitochondria and peroxisomes, and apoplastic space (Veitch, 2004; Sofo et al., 2015). Further, APX activity increases along with other enzymes activities, such as CAT, SOD, and GSH reductase (Shigeoka et al., 2002). In another study, $\mathrm{Cd}$ and $\mathrm{Cu}$ exposures caused the increase in APX and SOD activities (Lee et al., 2007). These results emphasize that Si-mediated scavenging of Cd-induced ROS might be correlated with APX and SOD but not POD in Alfalfa plants.

Our studies also revealed the increase of methionine and proline due to Si treatment on Cd-stressed plants. Methionine can undergo ROS-mediated oxidation to methionine sulfoxide by methionine sulfoxide reductases to ameliorate oxidative damage (Dos Santos et al., 2005; Cabreiro et al., 2006). Also, methionine is a substrate for the synthesis of various polyamines (putrescine, spermidine, spermine) associated with stress tolerance (Alcázar et al., 2010) and methionine residues act as an antioxidant protein reservoir (Hoshi and Heinemann, 2001). Apart from acting as an osmolyte, proline scavenges free radicals, stabilizes subcellular structures and proteins under stress conditions (Sharma and Dubey, 2005). Thus, our results suggest that induction of antioxidative metabolites help Alfalfa seedlings to adapt better to the Cd stress. Metal-induced proline accumulation in plants is not directly originated from heavy metal stress, but for water balance disorder by regulating the contents of inorganic solutes (Rai, 2002; Clemens, 2006). Furthermore, proline synthesis is advantageous to $\mathrm{NADP}^{+}$refilling and redox cycling, which is of particular importance for antioxidant defense mechanisms in plants during stress (Babiychuk et al., 1995). In this study, Si did not affect the concentration of glutathione and cysteine, which is correlated with the PC accumulation in roots as these two metabolites are involved in PC biosynthesis pathway. Therefore, it turned out that the active involvement of ROS scavenging mainly mediated by elevated SOD, methionine and proline was related, at least in part, to the Si-mediated alleviation of Cd stress in Alfalfa.

\section{CONCLUSION}

In this present study, morpho-physiological findings support that Si plays a critical role to withstand Cd toxicity and to restore the normal growth and development in Alfalfa plants. Further, simultaneous reduction of $\mathrm{Cd}$ and $\mathrm{Fe}$ in roots and shoots of Alfalfa due to Si treatment under Cd stress indicates that mechanisms counteracting Cd toxicity exist in roots. Further, no changes of metal chelator (MsPCS1 and MsMT2) genes and PC synthesis in roots suggest that changes in metal sequestration may not be involved in Si-mediated mitigation of Cd toxicity in Alfalfa. Also, reduction of Fe-reductase activity, downregulation of Fe-related genes (MsIRT1, MsNramp1, and MsFRO1) and 
a decrease of $\mathrm{Fe}$ chelators (citrate and malate) reveals that alleviation of Cd toxicity in Alfalfa plants largely depends on the inhibition of Fe uptake and Fe chelation in roots. Finally, a Si-mediated increase in antioxidant enzymes (CAT, SOD, APX) and metabolites (methionine, proline) might play an integral part against Cd-induced oxidative stress in Alfalfa plants. These findings may stimulate further researches for phytoremediation and development of Cd-tolerant crops through Si treatment.

\section{AUTHOR CONTRIBUTIONS}

AK conduced most of the laboratory works and prepared the draft manuscript. $\mathrm{MH}$ and $\mathrm{MK}$ performed few laboratory works. $\mathrm{AM}$ and $\mathrm{SH}$ revised the manuscript.

\section{REFERENCES}

Abadia, J., Lopez-Millan, A. F., Rombola, A., and Abadia, A. (2002). Organic acids and Fe-deficiency-a review. Plant Soil 241, 75-86. doi: 10.1023/ A: 1016093317898

Alcázar, R., Altabella, T., Marco, F., Bortolotti, C., Reymond, M., Koncz, C., et al. (2010). Polyamines: molecules with regulatory functions in plant abiotic stress tolerance. Planta 231, 1237-1249. doi: 10.1007/s00425-010-1130-0

Alexieva, V., Sergiev, I., Mapelli, S., and Karanov, E. (2001). The effect of drought and ultraviolet radiation on growth and stress markers in pea and wheat. Plant Cell Environ. 24, 1337-1344. doi: 10.1046/j.1365-3040.2001. 00778.x

Almeselmani, M., Deshmukh, P. S., Sairam, R. K., Kushwaha, S. R., and Singh, T. P. (2006). Protective role of antioxidant enzymes under high temperature stress. Plant Sci. 171, 382-388. doi: 10.1016/j.plantsci.2006.04.009

Anjum, N. A., Aref, I. M., Duarte, A. C., Pereira, E., Ahmad, I., and Iqbal, M. (2014). Glutathione and proline can coordinately make plants withstand the joint attack of metal(loid) and salinity stresses. Front Plant Sci. 5:662. doi: 10.3389/fpls.2014.00662

Babiychuk, E., Kushnir, S., Belles-Boix, E., Van Montagu, M., and Inzé, D. (1995). Arabidopsis thaliana NADPH oxidoreductase homologs confer tolerance of yeasts toward the thiol-oxidizing drug diamide. J. Biol. Chem. 270, 2622426231. doi: 10.1074/jbc.270.44.26224

Barcelo, J., Poschenrieder, C., Vazquez, M. D., Gunse, B., and Vernet, J. P. (1993). Beneficial and toxic effects of chromium in plants: solution culture, pot and field studies. Studies in Environmental Science No. 55. Paper Presented at the 5th International Conference on Environmental Contamination, Morges.

Bharwana, S. A., Ali, S., Farooq, M. A., Iqbal, N., Abbas, F., and Ahmad, M. S. A. (2013). alleviation of lead toxicity by silicon is related to elevated photosynthesis, antioxidant enzymes suppressed lead uptake and oxidative stress in cotton. J. Bioremed. Biodeg. 96, 242-249. doi: 10.1016/ j.ecoenv.2013.07.006

Bolwell, G. P., Bindschedler, L. V., Blee, K. A., Butt, V. S., Davies, D. R., Gardner, S. L., et al. (2002). The apoplastic oxidative burst in response to biotic stress in plants: a three-component system. J. Exp. Bot. 53, 1367-1376. doi: 10.1093/ jexbot/53.372.1367

Cabreiro, F., Picot, C. R., Friguet, B., and Petropoulos, I. (2006). Methionine sulfoxide reductases. Ann. N. Y. Acad. Sci. 1067, 37-44. doi: 10.1196/annals.1354.006

Carrasco-Gil, S., Estebaranz-Yubero, M., MedelCuesta, D., Millan, R., and Hernandez, L. E. (2012). Influence of nitrate fertilization on Hg uptake and oxidative stress parameters in alfalfa plants cultivated in a Hg-polluted soil. Environ. Exp. Bot. 75, 16-24. doi: 10.1016/j.envexpbot.2011.08.013

Caverzan, A., Passaia, G., Rosa, S. B., Ribeiro, C. W., Lazzarotto, F., and MargisPinheiro, M. (2012). Plant responses to stresses: role of ascorbate peroxidase in the antioxidant protection. Genet. Mol. Biol. 35, 1011-1019. doi: 10.1590/S141547572012000600016

\section{ACKNOWLEDGMENTS}

Authors are grateful to DNA Technology, Denmark, for supplying primers on a timely basis. Tommy Landberg, Department of Ecology, Environment and Plant Sciences, Stockholm University, Sweden provided the phytochelatin standards.

\section{SUPPLEMENTARY MATERIAL}

The Supplementary Material for this article can be found online at: http://journal.frontiersin.org/article/10.3389/fpls.2016. 01117

Clemens, S. (2006). Toxic metal accumulation, responses to exposure and mechanisms of tolerance in plants. Biochimie 88, 1707-1719. doi: 10.1016/j.biochi.2006.07.003

Cobbett, C. S. (2000). Phytochelatins and their roles in heavy metal detoxification. Plant Physiol. 123, 825-832.

Cobbett, C. S., and Goldsbrough, P. (2002). Phytochelatins and metallothioneins: roles in heavy metal detoxification and homeostasis. Annu. Rev. Plant Physiol. Plant Mol. Biol. 53, 159-182. doi: 10.1146/annurev.arplant.53.100301.135154

Curie, C., Alonso, J. M., Jean, M. L., Ecker, J. R., and Briat, J.-F. (2000). Involvement of NRAMP1 from Arabidopsis thaliana in iron transport. Biochem. J. 347, 749-755. doi: 10.1042/bj3470749

DalCorso, G., Farinati, S., and Furini, A. (2010). Regulatory networks of cadmium stress in plants. Plant Signal. Behav. 5, 663-667. doi: 10.4161/psb.5.6.11425

Dos Santos, C. V., Cuiné, S., Rouhier, N., and Rey, P. (2005). The Arabidopsis plastidic methionine sulfoxide reductase B proteins. Sequence and activity characteristics, comparison of the expression with plastidic methionine sulfoxide reductase A, and induction by photooxidative stress. Plant Physiol. 138, 909-922. doi: 10.1104/pp.105.062430

Farooq, M. A., Ali, S., Hameed, A., Ishaque, W., Mahmood, K., and Iqbal, Z. (2013). Alleviation of cadmium toxicity by silicon is related to elevated photosynthesis, antioxidant enzymes; suppressed cadmium uptake and oxidative stress in cotton. Ecotoxicol. Environ. Saf. 96, 242-249. doi: 10.1016/j.ecoenv.2013.07.006

Fusco, N., Micheletto, L., Dal Corso, G., Borgato, L., and Furini, A. (2005). Identification of cadmium-regulated genes by cDNA-AFLP in the heavy metal accumulator Brassica juncea L. J. Exp. Bot. 56, 3017-3027. doi: $10.1093 /$ jxb/eri299

Gong, H., Zhu, X., Chen, K., Wang, S., and Zhang, C. (2005). Silicon alleviates oxidative damage of wheat plants in pots under drought. Plant Sci. 169, 313-321. doi: 10.1016/j.plantsci.2005.02.023

Goud, P. B., and Kachole, M. S. (2012). Antioxidant enzyme changes in neem, pigeonpea and mulberry leaves in two stages of maturity. Plant Signal. Behav. 7, 1258-1262. doi: 10.4161/psb.21584

Greger, M., Kabir, A. H., Landberg, T., Maity, P. J., and Lindberg, S. (2016). Silicate reduces cadmium uptake into cells of wheat. Environ. Pollut. 211, 90-97. doi: 10.1016/j.envpol.2015.12.027

Greger, M., and Landberg, T. (2008). "Influence of silicon on cadmium in wheat," in Proceedings of the 4th International Conference on Silicon in Agriculture, ed. M. Laing (Durban: Aim Print), 25.

Guy, C., Haskell, D., Neven, L., Klein, P., and Smelser, C. (1992). Hydration-stateresponsive protein link cold and drought stress in spinach. Planta 188, 265-270. doi: $10.1007 / \mathrm{BF} 00216823$

Halliwell, B., and Foyer, C. H. (1978). Properties and physiological function of a glutathion reductase purified from spinach leaves by affinity chromotography. Planta 139, 9-17. doi: 10.1007/BF00390803

Hattab, S., Boussetta, H., and Banni, M. (2014). Influence of nitrate fertilization on Cd uptake and oxidative stress parameters in alfalfa plants cultivated in presence of Cd. J. Soil Sci. Plant Nutr. 14, 89-99. 
Hoagland, D. R., and Arnon, D. I. (1950). The water-culture method for growing plants without soil. Circ. Calif. Agric. Exp. Stn. 347:32.

Hoshi, T., and Heinemann, S. (2001). Regulation of cell function by methionine oxidation and reduction. J. Physiol. 531, 1-11. doi: 10.1111/j.1469-7793.2001.0001j.x

Hung, S., Yu, C., and Lin, C. H. (2005). Hydrogen peroxide functions as a stress signal in plants. Bot. Bull. Acad. Sin. 46, 1-10.

Irfan, M., Ahmad, A., and Hayat, S. (2014). Effect of cadmium on the growth and antioxidant enzymes in two varieties of Brassica juncea. Saudi J. Biol. Sci. 21, 125-131. doi: 10.1016/j.sjbs.2013.08.001

Ishikawa, S., Ishimaru, Y., Igura, M., Kuramata, M., Abe, T., Senoura, T., et al. (2012). Ion-beam irradiation, gene identification, and marker-assisted breeding in the development of low-cadmium rice. Proc. Natl. Acad. Sci. U.S.A. 109, 19166-19171. doi: 10.1073/pnas.1211132109

Järup, L., and Åkesson, A. (2009). Current status of cadmium as an environmental health problem. Toxicol. Appl. Pharmacol. 238, 201-208. doi: 10.1016/j.taap.2009.04.020

Jasinski, M., Ducos, E., Martinoia, E., and Bountry, M. (2003). The ATP-binding cassette transporters: structure, function, and gene family comparison between rice and Arabidopsis. Plant Physiol. 131, 1169-1177. doi: 10.1104/pp.102. 014720

Jeong, J., and Connolly, E. L. (2009). Iron uptake mechanisms in plants: functions of the FRO family of ferric reductases. Plant Sci. 176, 709-714. doi: 10.1016/j.plantsci.2009.02.011

Kabir, A. H. (2016). Biochemical and molecular changes in rice seedlings (Oryza sativa L.) to cope with chromium stress. Plant Biol. (Stuttg) 18, 710-719. doi: $10.1111 /$ plb.12436

Kabir, A. H., Paltridge, N. G., Able, A. J., Paull, J. G., and Stangoulis, J. C. R. (2012). Natural variation for Fe-efficiency is associated with upregulation of Strategy I mechanisms and enhanced citrate and ethylene synthesis in Pisum sativum L. Planta 235, 1409-1419. doi: 10.1007/s00425-011-1583-9

Kabir, A. H., Rahman, M. M., Haider, S. A., and Paul, N. K. (2015). Mechanisms associated with differential tolerance to Fe deficiency in okra (Abelmoschus esculentus Moench). Environ. Exp. Bot. 112, 16-26. doi: 10.1016/j.envexpbot.2014.11.011

Kumar, A., Dwivedi, S., Singh, R. P., Chakrabarty, D., Mallick, S., Trivedi, P. K., et al. (2014). Evaluation of amino acid profile in contrasting arsenic accumulating rice genotypes under arsenic stress. Biol. Plant. 58, 733-742. doi: 10.1016/j.jhazmat.2012.06.049

Lee, S. H., Ahsan, N., Lee, K. W., Kim, D. H., Lee, D. G., Kwak, S. S., et al. (2007). Simultaneous overexpression of both CuZn superoxide dismutase and ascorbate peroxidase in transgenic tall fescue plants confers increased tolerance to a wide range of abiotic stresses. J. Plant Physiol. 164, 1626-1638. doi: 10.1016/j.jplph.2007.01.003

Lichtenthaler, H. K., and Wellburn, A. R. (1985). Determination of total carotenoids and chlorophylls $\mathrm{a}$ and $\mathrm{b}$ of leaf in different solvents. Biochem. Soc. Trans. 11, 591-592. doi: 10.1042/bst0110591

Lindberg, S., Landberg, T., and Greger, M. (2007). Cadmium uptake and induction of phytochelatins in wheat protoplasts. Plant Physiol. Biochem. 45, 47-53. doi: 10.1016/j.plaphy.2007.01.001

Lindberg, S., Landberg, T., and Greger, M. (2004). A new method to detect cadmium uptake in protoplasts. Planta 219, 526-532. doi: 10.1007/s00425-004$1256-\mathrm{Z}$

Ling, H. Q., Bauer, P., Bereczky, Z., Keller, B., and Ganal, M. (2002). The tomato fer gene encoding a bHLH protein controls iron-uptake responses in roots. Proc. Nat. Aca. Sci. U.S.A. 99, 13938-13943. doi: 10.1073/pnas.212448699

Liu, J., Ma, J., He, C., Li, X., Zhang, W., Xu, F., et al. (2013). Inhibition of cadmium ion uptake in rice (Oryza sativa) cells by a wall-bound form of silicon. New Phytol. 200, 691-699. doi: 10.1111/nph.12494

Lutts, S., Kinet, J. M., and Bouharmont, J. (1996). NaCl-induced senescence in leaves of rice (Oriza sativa L.) cultivar differing in salinity resistance. Ann. Bot. 78, 389-398. doi: 10.1006/anbo.1996.0134

Ma, J. F., Yamaji, N., Mitani, N., Xu, X. X., Su, Y. H., McGrath, S. P., et al. (2008). Transporters of arsenite in rice and their role in arsenic accumulation in rice grain. Proc. Nat. Aca. Sci. U.S.A. 105, 9931-9935. doi: 10.1073/pnas.0802361105

Malar, S., Vikram, S. S., Favas, P. J. C., and Perumal, V. (2014). Lead heavy metal toxicity induced changes on growth and antioxidative enzymes level in water hyacinths [Eichhornia crassipes (Mart.)] Bot. Stud. 55:54.
Metwally, A., Safronova, V. I., Belimov, A. A., and Dietz, K. (2004). Genotypic variation of the response to cadmium toxicity in Pisum sativum L. J. Exp. Bot. $56,167-178$.

Morel, M., Crouzet, J., Gravot, A., Auroy, P., Leonhardt, N., Vavasseur, A., et al. (2009). AtHMA3, a P1B-ATPase allowing Cd / Zn / Co / Pb vacuolar storage in Arabidopsis. Plant Physiol. 149, 894-904. doi: 10.1104/pp.108. 130294

Naeem, A., Saifullah, Ghafoor, A., and Farooq, M. (2015). Suppression of cadmium concentration in wheat grains by silicon is related to its application rate and cadmium accumulating abilities of cultivars. J. Sci. Food Agric. 95, 2467-2472. doi: $10.1002 /$ jsfa.6976

Nakanishi, H., Ogawa, I., Ishimaru, Y., Mori, S., and Nishizawa, N. K. (2006). Iron deficiency enhances cadmium uptake and translocation mediated by the $\mathrm{Fe} 2+$ transporters OsIRT1 and OsIRT2 in rice. Soil Sci. Plant Nutr. 52, 464-469. doi: 10.1111/j.1747-0765.2006.00055.x

Peralta-Videa, J. R., Gardea-Torresdey, J. L., Gomez, E., Tiemann, K. J., Parsons, J. G., and Carrillo, G. (2002). Effect of mixed cadmium, copper, nickel and zinc at different $\mathrm{pHs}$ upon alfalfa growth and heavy metal uptake. Environ. Pollut. 119, 291-301. doi: 10.1016/S0269-7491(02)00105-7

Pourghasemiana, N., Ehsanzadeha, P., and Greger, M. (2013). Genotypic variation in safflower (Carthamus spp.) cadmium accumulation and tolerance affected by temperature and cadmium levels. Environ. Exp. Bot. 87, 218-226. doi: 10.1016/j.envexpbot.2012.12.003

Rai, V. K. (2002). Role of amino acids in plant responses to stresses. Biol. Plant. 45, 481-487. doi: 10.1023/A:1022308229759

Rascio, N., and Navarri-Izzo, F. (2011). Heavy metal hyperaccumulating plants: how and why do they do it? And what makes them so interesting. Plant Sci. 180, 169-181. doi: 10.1016/j.plantsci.2010.08.016

Rogers, E. E., Eide, D. J., and Guerinot, M. L. (2000). Altered selectivity in an Arabidopsis metal transporter. Proc. Natl. Acad. Sci. U.S.A. 97, 12356-12360. doi: $10.1073 /$ pnas. 210214197

Romero-Puertas, M. C., Corpas, F. J., Rodriguez-Serrano, M., Gomez, M., del Río, L. A., and Sandalio, L. M. (2007). Differential expression and regulation of antioxidative enzymes by cadmium in pea plants. J. Plant Physiol. 164, 1346-1357. doi: 10.1016/j.jplph.2006.06.018

Schützendübel, A., and Polle, A. (2002). Plant responses to abiotic stresses: heavy metal-induced oxidative stress and protection by mycorrhization. J. Exp. Bot. 53, 1351-1365. doi: 10.1093/jexbot/53.372.1351

Semane, B., Cuypers, A., Smeets, K., Van Belleghem, F., Horemans, N., Schat, H., et al. (2007). Cadmium responses in Arabidopsis thaliana: glutathione metabolism and antioxidative defence system. Physiol. Plant. 129, 519-528. doi: 10.1111/j.1399-3054.2006.00822.x

Shanker, A. K., Cervantes, C., Loza-Tavera, H., and Avudainayagam, S. (2005). Chromium toxicity in plants. Environ. Int. 31, 739-753. doi: 10.1016/j.envint.2005.02.003

Sharma, S. S., and Dietz, K. (2006). The significance of amino acids and amino acid-derived molecules in plant responses and adaptation to heavy metal stress. J. Exp. Bot. 57, 711-726. doi: 10.1093/jxb/erj073

Sharma, P., and Dubey, R. S. (2005). Modulation of nitrate reductase activity in rice seedlings under aluminium toxicity and water stress: role of osmolytes as enzyme protectant. J. Plant Physiol. 162, 854-864. doi: 10.1016/j.jplph.2004.09.011

Shigeoka, S., Ishikawa, T., Tamoi, M., Miyagawa, Y., Takeda, T., Yabuta, Y., et al. (2002). Regulation and function of ascorbate peroxidase isoenzymes. J. Exp. Bot. 53, 1305-1319. doi: 10.1093/jexbot/53.372.1305

Sofo, A., Scopa, A., Nuzzacu, M., and Vitti, A. (2015). Ascorbate peroxidase and catalase activities and their genetic regulation in plants subjected to drought and salinity stresses. Int. J. Mol. Sci. 16, 13561-13578. doi: 10.3390/ijms16061 3561

Sun, M., and Zigman, S. (1978). An improved spectrophotomeric assay for superoxide dismutase based on epinephrine autoxidation. Anal. Biochem. 90, 81-89. doi: 10.1016/0003-2697(78)90010-6

Takahashi, R., Ishimaru, Y., Senoura, T., Shimo, H., Ishikawa, S., Arao, T., et al. (2011). The OsNRAMP1 iron transporter is involved in Cd accumulation in rice. J. Exp. Bot. 62, 4843-4850. doi: 10.1093/jxb/err 136

Treder, W., and Cieslinski, G. (2005). Effect of silicon application on cadmium uptake and distribution in strawberry plants grown on contaminated soils. $J$. Plant Nutr. 28, 917-929. doi: 10.1081/PLN-200058877 
Veitch, N. (2004). Horseradish peroxidase: a modern view of a classical enzyme. Phytochem. 65, 249-259. doi: 10.1016/j.phytochem.2003. 10.022

Vert, G., Grotz, N., Dedaldechamp, F., Gaymard, F., Guerinot, M. L., Briat, J., et al. (2002). IRT1, an Arabidopsis transporter essential for iron uptake from the soil and for plant growth. Plant Cell 14, 1223-1233. doi: 10.1105/tpc. 001388

Weber, M., Trampczynska, A., and Clemens, S. (2006). Comparative transcriptome analysis of toxic metal responses in Arabidopsis thaliana and the $\mathrm{Cd}(2+)$ hypertolerant facultative metallophyte Arabidopsis halleri. Plant Cell Environ. 29, 950-963. doi: 10.1111/j.1365-3040.2005.01479.x

Wu, J., Guo, J., Hu, Y., and Gong, H. (2015). Distinct physiological responses of tomato and cucumber plants in silicon-mediated alleviation of cadmium stress. Front. Plant Sci. 6:453. doi: 10.3389/fpls.2015.00453

Yan, Y., Choi, D., Kim, D., and Lee, B. (2010). Genotypic variation of cadmium accumulation and distribution in rice. J. Crop Sci. Biotechnol. 13, 69-73. doi: $10.1002 /$ jsfa.4355

Yang, J., Teng, Y., Wang, J., and Li, J. (2011). Vanadium uptake by alfalfa grown in V-Cd-contaminated soil by pot experiment. Biol. Trace Elem. Res. 142, 787-795. doi: $10.1007 /$ s12011-010-8777-z
Zhang, C., Wang, L., Nie, Q., Zhang, W., and Zhang, F. (2008). Long-term effects of exogenous silicon on cadmium translocation and toxicity in rice (Oryza sativa L.). Environ. Exp. Bot. 62, 300-307. doi: 10.1016/j.envexpbot.2007. 10.024

Zhu, Z., Wei, G., Li, J., Qian, Q., and Yu, J. (2004). Silicon alleviates salt stress and increases antioxidant enzymes activity in leaves of saltstressed cucumber (Cucumis sativus L.). Plant Sci. 167, 527-533. doi: 10.1016/j.plantsci.2004.04.020

Conflict of Interest Statement: The authors declare that the research was conducted in the absence of any commercial or financial relationships that could be construed as a potential conflict of interest.

Copyright (c) 2016 Kabir, Hossain, Khatun, Mandal and Haider. This is an openaccess article distributed under the terms of the Creative Commons Attribution License (CC BY). The use, distribution or reproduction in other forums is permitted, provided the original author(s) or licensor are credited and that the original publication in this journal is cited, in accordance with accepted academic practice. No use, distribution or reproduction is permitted which does not comply with these terms. 